\title{
Protein SI00B: a potential biomarker for brain damage in paediatric patients with congenital heart disease?
}

\begin{abstract}
Objective: S100B protein has been implicated as a biomarker of brain injury in several clinical conditions. The aim of this study is to determine and to correlate concentrations of the protein within preoperative conditions in pediatric population with congenital heart disease: with perinatal suffering, neurological pathological antecedents, arterial $\mathrm{O}_{2}$ saturation and oxidative stress parameters values.
\end{abstract}

Material and Methods: We measured serum levels of S100 $\beta$, lactate, nitrates, Nitrites, Malondialdehyde and total antioxidant capacity in the pre-operative period of 72 pediatric patients with congenital heart disease: 47 of them with perinatal neurological history (fetal suffering) and 25 of them without such antecedents.

Results: Patients with perinatal suffering and neurological background showed higher maximum lactate levels after cardiac surgery [3.2 (2.3-4.8) $\mathrm{mmol} / \mathrm{L} ; \mathrm{p}=0.005]$. As well as higher seric concentration of $\mathrm{S} 100 \beta$ protein $[0.0188(0.0155-0.0478) \mathrm{ug} / \mathrm{l} ; \mathrm{p}=0.0 .019]$ (micrograms), when compared to the group without such clinical history. An inversely proportional correlation was observed when $\mathrm{S} 100 \beta$ concentration was compared with total antioxidant capacity. At serum levels of $0.188 \mathrm{u} / 1$ (nanograms) of $\mathrm{S} 100 \beta$ the sensitivity/ specificity curve (ROC) was respectively $51 \%$ and $72 \%$.

Conclusion: Although we do not know the true clinical significance and the specific anatomical substrate that induces the release of the S100 $\beta$ it can be considered as a biomarker of brain damage, only if complemented with other parameters such as lactate and total antioxidant capacity.

Keywords: biomarker, neurological damage, congenital heart disease, S100B
Volume 4 Issue 3 - 2018

\author{
Luis Antonio Pando-Orellana, Juan Calderón- \\ Colmenero, Nancy Lucero Martínez- \\ Rodriguez, Leonardo Del Valle-Mondragón, \\ Victor Manuel Espinoza-Gutiérrez, Jorge Luis \\ Cervantes-Salazar, Pedro Curi-Curi, Juan \\ Verdejo-Paris, Alfonso Buendía-Hernández \\ Escuela Nacional de Ciencias Biológicas, Instituto Politécnico \\ Nacional, México
}

Correspondence: Luis Antonio Pando-Orellana, Artemio de Valle Arizpe \#I6-I0I, Col Del Valle, Delegación Benito Juárez, C.P. 03100 , México D.F. Escuela Nacional de Ciencias Biológicas, Instituto Politécnico Nacional, México, Tel 0 I (52)555232684, Fax 0 I(52)555232983,Email drpando@hotmail.com

Received: June 14, 2018 | Published: June 29, 2018
Abbreviations: $\mathrm{NO}$, nitrogenmonoxide; $\mathrm{NO}_{2}$, nitrite anion; MDA, malondialdehyde; CPB, cardiopulmonary bypass; TAC, total antioxidant capacity; PBP, pulmonary bypass; CVE, cerebral vascular events; ALZ, alzheimer

\section{Introduction}

Congenital heart disease is the commonest malformation in paediatrics, with a prevalence of 6 to 8 cases for each 1000 newborns alive. The advances in the diagnosis and the surgical techniques and the peri-operatory handling, have permitted that many patients reach adult life; but the possibility of damage to the central nervous system , continuous to be one of the most feared associated morbidities in cardiovascular surgery. ${ }^{1,2}$ The presence of a vast variety of neurodevelopmental alterations has been identified; up to a $50 \%$ of children, with corrected congenital heart disease, but unfortunately, we cannot predict it's possible appearance: the diagnosis depends on neurological examinations, neurophisiological studies, imagenological scanning such as: computed tomography, PET/CT, AMR with or without spectroscopy, SPECT, among others.

These studies cannot be accomplished immediately, because of hemodynamic instability, critical condition of patients, not availability of the infrastructure or the cost itself of the study. Besides, not always these studies can supply always the desired information regarding the sensibility or the specificity in clinical terms to evaluate and quantify the exact measure of the neurological insult and neither can predict it's outcome. ${ }^{3,4}$

The need for a biomarker is therefore needed not only to determine neuronal damage but to predict it's evolution and outcome. The protein $\mathrm{S} 100 \beta$, abundant in the brain, produced by astrocytes in physiological conditions has been used in different clinical situations: $\mathrm{CET}$, cerebral ischemia, cerebral tumors, neurodegenerative disorders or during chronical inflammatory cerebral disease..$^{5-11}$ In cardiac arrest as well elevation of $\mathrm{S} 100 \beta$ as well as cardiopulmonary bypass associated to neurological suffering because of cardiovascular surgical complications. ${ }^{12,13}$ This increment of serical values of the $S 100 \beta$ has been mentioned as evidence of permeability of the BBB and CI. ${ }^{14,15}$

The objective of the present study was to determine and to correlate the serum concentration of $S 100 \beta$ protein in pediatric population with congenital heart disease with perinatal neurological antecedents (particularly fetal suffering) and neurological antecedents during developemental period prior to surgery, with oxygen saturation, oxidative stress in a period before it's surgical correction of the cardiopathy.

\section{Material and methods}

This study is analytical, prospective and transversal study of patients admitted to the cardiopediatry department with an age $<18$ 
years of age, that were submitted to surgical elective correction of their congenital heart disease with or without cardiopulmonary bypass in a period of 3 months.

The exclusion criteria were antecedent of previous cardiothoracic surgery or emergency cardiac catheterism. Clinical history was completed in all patients included, considering gender, anthropometric measures, $\mathrm{O}_{2}$ saturation presurgical, pathological and syndromatical antecedents, perinatal-history PBP requirement, time under bypass, aortic clamping, special emphasis in fetal suffering and Apgar score $\left(1-5^{\prime}\right)$ after birth, cardiac arrest, neurodevelopment, metabolic issues and convulsions.

Patients were divided in one group with neurological perinatal antecedents and a second group without such antecedents. The evolution was monitored until it's withdraw from hospital with particular interest in neurological morbidity.

\section{Sample processing}

Peripheral blood samples were obtained from the patients included in the study, previous to cardiac corrective surgery. Such samples were extracted through venous puncture and centrifugated at $3000 \mathrm{rpm}$ during $15^{\prime}$ at room temperature. Aliquotes were obtained from the serum and proceeded to freeze the samples down to $-80^{\circ} \mathrm{C}$ until their analysis. Levels of $\mathrm{S} 100 \beta$ were measured as well as concentration of Malondialdehyde, nitrites, nitrates and TAC.

\section{Concentration of $\mathrm{SIOO} \beta$}

The concentration of $\mathrm{S} 100 \beta$ was measured by ELISA technique with two incubation periods with a total time of 120 minutes. During the first incubation period a monoclonal specific antibody was added (biotinilated anti $\mathrm{S} 100 \beta$ antibody) for a period of 60 minutes. Afterwards, it was added conjugated HRP-estreptavidine; which after 30 minutes of incubation and washing, was permitted to react with the substrate solution. The reaction was stopped by the addition of an acid solution and the absorbance of the resulting product was measured: which results proportional to the concentration of S100ß.

A standard curve was constructed representing the values of absorbance against concentrations that were expressed in micrograms $/ 1$.

\section{Malondialdehayde (MDA)}

This molecule, was determined in serum by capillary zone electrophoresis, the sample was desproteinizeised, with cold methanol, in a proportion 1:1.Proceeded to centrifuge at $16000 \mathrm{xg}$ during $15^{\prime}$ and purified with nitrocellulose membrane filters of $0.22 \mathrm{um}$ (Millipore, Billerica, MA, USA).Then it was diluted 1:10 with cold sodium hydroxide $0.1 \mathrm{M}$ and analyzed directly. This was done using a P/ACE ${ }^{\text {tm} M D Q ~ s y s t e m ~ B e c k m a n ~ C o u l t e r ~ t o ~ w h i c h ~ i t ~ w a s ~ p r e a c o n d i t i o n e d ~ t h e ~}$ capillary by passing through a $0.1 \mathrm{M}$ solution of hydroxide sodium during a period of 10 minutes, afterwards for another 10 minutes distilled water and finally a buffer for the last 10 minutes (borates $10 \mathrm{mM}+\mathrm{CTAB} 0.5 \mathrm{mM}$ at a $\mathrm{pH}$ of 9.0 ).

The samples were injected under hydrodynamic pressure at 0.5 psi/10s.Separation was accomplished along 4 minutes with $-25 \mathrm{kV}$ at $267 \mathrm{~nm}$. The capillary was washed between the procedures with sodium hydroxide $0.1 \mathrm{M}$ for 2 minutes, distilled water for another 2 minutes and buffer for 4 minutes. The concentration of MDA was expressed in $\mathrm{uM}$ and through a standard curve.

\section{Nitrites and nitrates}

The quantification of nitrites and nitrates was performed at $37^{\circ} \mathrm{C}$. We added $100 \mathrm{uL}$ of the sample $+100 \mathrm{ul}$ of saturated vanadium chloride in clorhidric acid $1 \mathrm{M}$.Homogenized vigorously and then added $100 \mathrm{uL}$ of a mixture $1: 1$ of sulfanilamide $2 \%$ recently prepared in chlorhydric acid at $5 \%$ conc. and $\mathrm{N}-(1$ naftil)-etilendiamina in $0.1 \%$ distilled water. Gently homogenized and immediately read at $540 \mathrm{~nm}$. In both determinations the 0 absorbance was adjusted with a mixture of reactive. The concentrations of nitrites and nitrates were determined through respective curves sodium nitrite and nitrate grade HPLC humidity free in a range of 0 to 500 pmoles $/ \mathrm{mL}$.

\section{Total antioxidative capacity (TAC)}

The CUPRAC methodology was applied ${ }^{16} \mathrm{In}$ an assay tube $1 \mathrm{ml}$ of $\mathrm{CuCl}_{2} 1 \times 10-2 \mathrm{M}+1 \mathrm{ml}$ of neocuproine $7.5 \times 10-3 \mathrm{M}$ and a solution of ammonium acetate at a $\mathrm{pH}$ of 7 ,these as a chromogenic agent. Afterwards the extracts prepared in water $(1.1 \mathrm{xml})$ to complete a final volume of $4.1 \mathrm{ml}$. The assay tubes were sealed and after 30 minutes of incubation an absorbance of $450 \mathrm{~nm}$ was registered against a reactive blank. In order to determine equivalence in Trolox units (umoles per gram of extract) we used a value of ETrolox=1.67x104Lmol-cm-1.

\section{Statistical analysis}

We used conventional statistical analysis of central tendency to resume the main characteristics of the sample. In the exploratory analysis, the numerical data had a different distribution than the normal standard. The comparison of the numerical variables between individuals with neurological perinatal antecedents with the ones that did not had them, was done with the test of U-Mann Whitney and the data are presented as median and percentiles 25 and 75 . The categorical variables were analyzed with the test of Fisher when required and are presented as absolute frequencies and proportions. The statistical significance was established in $p=<0.05$. To study the correlation between $S 100 \beta$ and ordinal variables and discrete quantitative it was used the Spearman correlation.

$\mathrm{S} 100 \beta$ as a dependent variable was submitted to logarithmic transformation, after confirming the corresponding suppositions; we applied a lineal regression analysis in order to identify the variables that would explain better the risk of developing neurological issues in the studied groups.

The model was constructed one variable at a time. The final model included variables with biological relevance, with statistical relevance or both. The co variables included in the model were the ones that presented a coefficient $=0.3$ with a $p<0.15$ complying with this and adjusting to one variable the TAC.

The reference values of $S 100 \beta$ were calculated in pediatric population with perinatal antecedents by means of a ROC curve (sensibility and sensitivity curve) for differences between groups with and without perinatal antecedents (basically hypoxic). The data were analyzed with the program SPSS version 18.0 (SPSS, Chicago Il) and STATA version 11.0. 


\section{Results}

72 Patients were included for the final analysis, which were divided in 2 groups: 47 of them with neurological perinatal antecedents $(52 \%$ of them masculine), and 25 of them without these antecedents. The demographic and clinical characteristics are shown in Table 1.

We can observe that the group with neurological perinatal antecedents had significant differences in presence of congenital cyanotic heart disease $[61.7 \%(n=29) ; p=0.0 .001]$, pathological antecedents [68\% [68\%(n=32); $\mathrm{p}=0.009]$, brain damage suspected $[45 \%(n=21) ; p=0.001]$, chronic hypoxia $[79 \%(n=79 \% p=<0.000]$, and cardiac arrest event $[23 \%(\mathrm{n}=11) \mathrm{p}=0.032]$,compared to the group without perinatal antecedents.

The group with perinatal antecedents revealed higher statistically significant maximum post surgical lactate [3.2(2.3.4.8) $\mathrm{mmol} / \mathrm{L}$; $\mathrm{p}=0.005]$ and serum levels of protein $\mathrm{S} 100 \beta[0.0188(0.0155-0.0478)$ $\mathrm{ug} / \mathrm{L} ; \mathrm{p}=0.19]$ compared with the group without neurological perinatal antecedents. (Table 2)

Table I Characteristics demographics of study groups

\begin{tabular}{|c|c|c|c|}
\hline Variables & $\begin{array}{l}\text { With perinatal antecedents } \\
(n=47)\end{array}$ & $\begin{array}{l}\text { Without perinatal antecedents } \\
(n=25)\end{array}$ & $\mathbf{P}$ \\
\hline \multicolumn{4}{|l|}{ Gender } \\
\hline Male n (\%) & $24(51 \%)$ & $13(52 \%)$ & \multirow{2}{*}{0.94} \\
\hline Female $\mathrm{n}(\%)$ & $23(49 \%)$ & $12(48 \%)$ & \\
\hline Age (months/years) & $3(1-10)$ & $3(0.1-7)$ & 0.648 \\
\hline Weight (Kg) & $12(5.2-21)$ & $12.9(7.3-43.0)$ & 0.271 \\
\hline Congenital cyanotic heart disease & $29(61.70)$ & $8(32)$ & 0.016 \\
\hline $\mathrm{O}_{2}$ Saturation & $78(70-93)$ & 91 (85-94) & 0.004 \\
\hline Cardiopulmonar bypass & $4 \mid(87.23)$ & $23(92)$ & 0.54 \\
\hline Cardiopulmonar bypass (min) & $93(40-129)$ & $90(60-126)$ & 0.543 \\
\hline Transoperatory complications & $20(42.55)$ & $6(24)$ & 0.119 \\
\hline Postoperatory complications & $35(74.47)$ & $15(60)$ & 0.205 \\
\hline Sindromatic antecedents & $9(19)$ & $5(20)$ & 0.931 \\
\hline Pathological antecedents & $32(68)$ & $9(36)$ & 0.009 \\
\hline \multicolumn{4}{|l|}{ Perinatal antecedents } \\
\hline Fetal Suffering & II (23.40) & $3(12)$ & 0.244 \\
\hline Pre-eclampsia & $4(9)$ & $3(12)$ & 0.463 \\
\hline Eclampsia & $2(4)$ & 0 & 0.423 \\
\hline Apgar $<7$ & $25(53)$ & $15(60)$ & 0.58 \\
\hline Seizures & $2(4)$ & $2(8)$ & 0.433 \\
\hline Metabolic disorders, n (\%) & $5(11)$ & $2(8)$ & 0.537 \\
\hline Brain damage $n(\%)$ & $2 \mathrm{I}(45)$ & $2(8)$ & 0.001 \\
\hline
\end{tabular}

Table 2 Biochemical featurs of study groups

\begin{tabular}{|c|c|c|c|}
\hline Variable & $\begin{array}{l}\text { With antecedents perinatal } \\
(n=47)\end{array}$ & $\begin{array}{l}\text { Without antecedents perinatal } \\
(n=25)\end{array}$ & $\mathbf{P}$ \\
\hline Minimun lactate (mmol/L) & I.4 (I.I-I.7) & $1.2(1.1-1.4)$ & 0.076 \\
\hline Maximun lactate (mmol/L) & $3.2(2.3-4.8)$ & $2.1(1.5-2.6)$ & 0.005 \\
\hline Protein SI00ß (ug/L) & $0.0188(0.0155-0.0478)$ & $0.0155(0.0144-0.0211)$ & 0.019 \\
\hline Malondialdehide, MDA (pmoles/mL) & $0.427(0.181-1.021)$ & $0.448(0.139-0.933)$ & 0.438 \\
\hline TAC (moles/L) & $482.7(297.0-615.9)$ & $459.4(381.2-600.3)$ & 0.827 \\
\hline [NO] (pmoles/mL) & $10.2(7.2-15.0)$ & $12.3(6.3-17.0)$ & 0.594 \\
\hline$\left[\mathrm{NO}_{2}\right](\mathrm{mmoles} / \mathrm{mL})$ & $42.9(21.4-92.0)$ & $51.3(34.9-7 \mid .9)$ & 0.35 \\
\hline$\left[\mathrm{NO}_{3}\right](\mathrm{mmoles} / \mathrm{mL})$ & 318.9 (208.9-49।.7) & $287.6(70.0-366.1)$ & 0.172 \\
\hline
\end{tabular}


The correlation of S100 $\beta$ with biochemical parameters shows significant statistical differences between the group with individuals with neurological perinatal antecedents when correlated with TAC (Spearman's Rho $=-05166, \mathrm{p}=0.0002$ ), meaning that patients with perinatal antecedents mainly hypoxic with their cardiopathy with a descent in their levels of TAC presented elevated levels of S100 $\beta$. (Table 3) Which is represented in Figure 1. We did not observe any other biochemical correlation of $\mathrm{S} 100 \beta$ in this work.

Table 3 Correlation between protein leves and quantitative variables

\begin{tabular}{|c|c|c|c|}
\hline \multirow{2}{*}{$\begin{array}{l}\text { Variable (Spearman's rho) } \\
p<0.05\end{array}$} & $\begin{array}{l}\text { With perinatal antecedents } \\
(n=47)\end{array}$ & $\begin{array}{l}\text { Without perinatal antecedents } \\
(n=25)\end{array}$ & Total $(n=72)$ \\
\hline & \multicolumn{3}{|l|}{ Proteína SI00B (ug/L) } \\
\hline Age (months/years) & (0.1429) 0.3381 & $0.3469) 0.0893$ & (0.2II8) $0.074 \mid$ \\
\hline Minimun lactate (mmol/L) & $(0.0705) 0.6376$ & (0.0985) 0.6394 & (0.10I8) 0.3946 \\
\hline Maximun lactate (mmol/L) & $(0.0482) 0.7474$ & $(0.0700) 0.7396$ & (0.1082) 0.3656 \\
\hline Malondialdehide, MDA (pmoles/mL) & (0.1079) 0.4704 & $(0.1520) 0.4683$ & $0.0495) 0.6799$ \\
\hline TAC (moles/L) & $0.5166) 0.0002$ & (0.3892) 0.0545 & $0.4490) 0.0001$ \\
\hline [NO] (pmoles/mL) & $0.2608) 0.0766$ & (0.1277) 0.5431 & (0.10।8) 0.3947 \\
\hline$\left[\mathrm{NO}_{2}\right](\mathrm{mmoles} / \mathrm{mL})$ & $(0.2052) 0.1664$ & (0.0279) 0.8947 & (0.1099) 0.3582 \\
\hline$\left[\mathrm{NO}_{3}\right](\mathrm{mmoles} / \mathrm{mL})$ & (0.289) 0.0488 & (0.00I2) 0.9955 & (0.1957) 0.0995 \\
\hline
\end{tabular}

$\mathrm{R}$, spearman's rho, $\mathrm{p}<0.05$

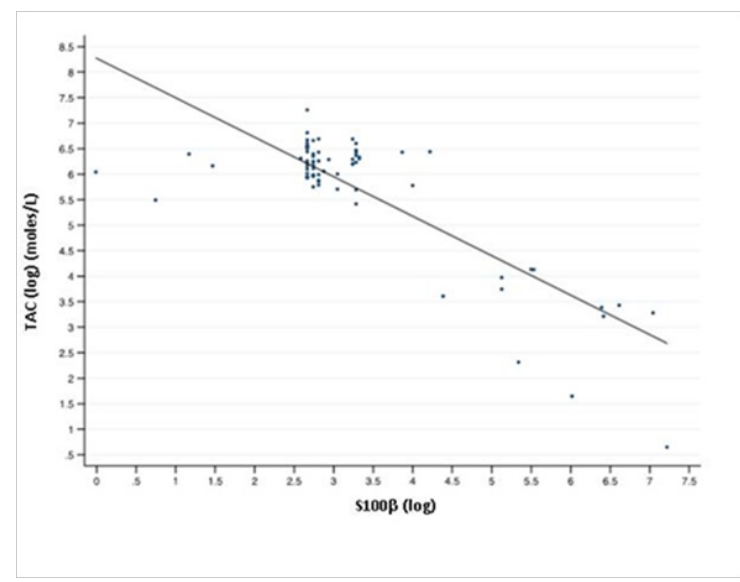

Figure I Scatter plot TAC $(\log )(\mathrm{mmoles} / \mathrm{L})$ and SI00 $\beta$ protein.
To study the relation and potential effect of confusion factors, we applied a linear regression model in the group with neurological perinatal antecedents. The only variable which maintained a significative statistical relation with levels of $\mathrm{S} 100 \beta$ was TAC $(\beta=-$ $0.864,95 \%$ confidence interval $=-1.001 \mathrm{a}-0.720, \mathrm{R} 2=0.6697, \mathrm{p}<0.000)$.

We posted the reference values of $\mathrm{S} 100 \beta$ in our total Pediatric population, by age <1year and >1year, by classification with and without perinatal antecedents. (Table 4) The Cohort dots of S100 $\beta$ were determined by ROC curves to determine the value of the protein in the presence or not of such perinatal neurological antecedents. (Table 5) The mayor area below the curve was $\mathrm{AUC}=0.6677(95 \%$ confidence interval 0.546-773) corresponding to a value of $\mathrm{S} 100 \beta$ of $0.188 \mathrm{ug} / \mathrm{L}$. The sensibility and specificity of this value to identify patients with perinatal antecedents was $51 \%$ and $72 \%$ respectively. (Figure 2)

Table 4 SI00 $\beta$ serum benchmarks (ug/L)

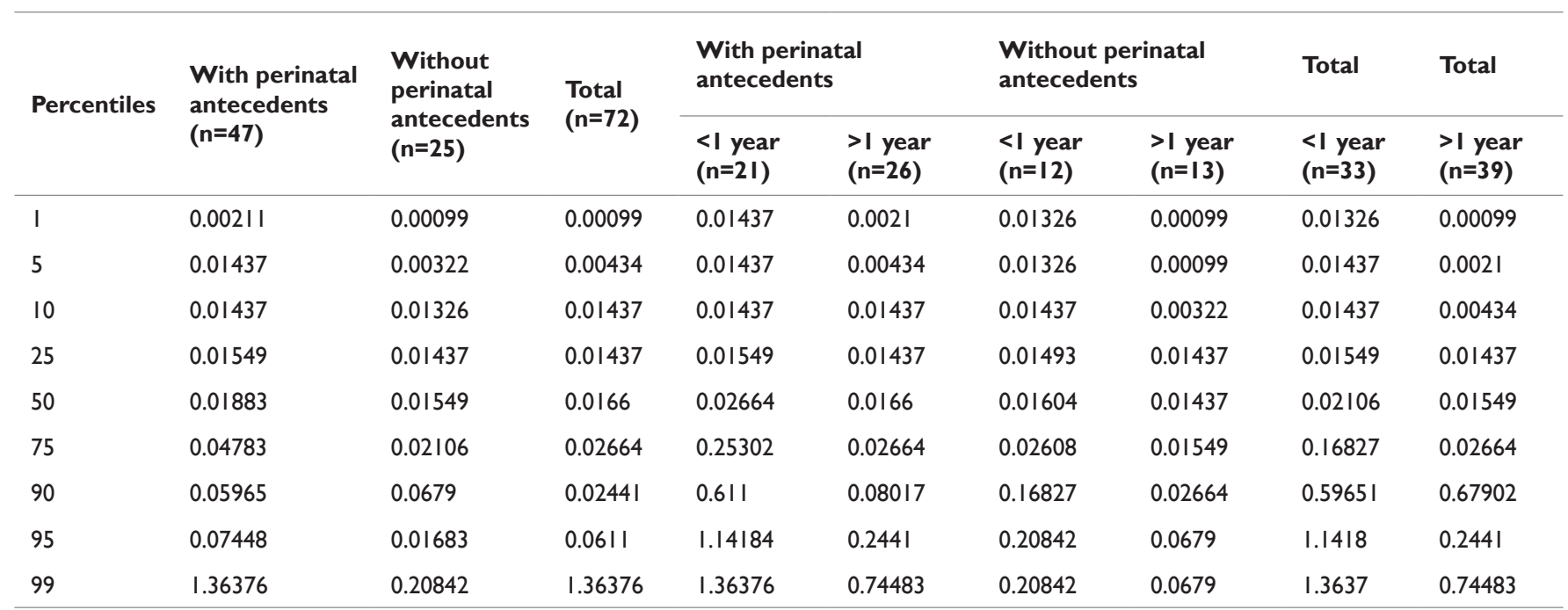




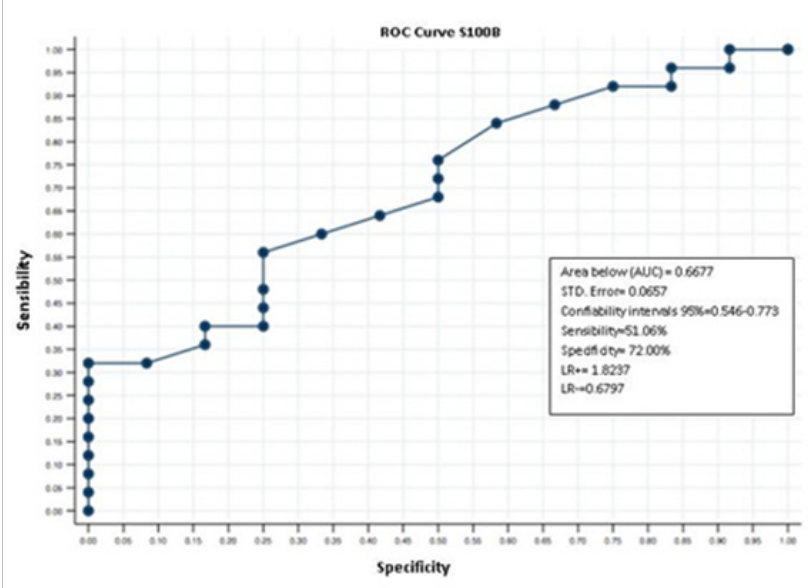

Figure 2 ROC Curve SI00B.

Table 5 Correlation between SI00 $\beta$ protein, saturation $\mathrm{O} 2$ and TAC

\begin{tabular}{lllll}
\hline Variables & $\boldsymbol{\beta}$ & $\begin{array}{l}\text { IC 95\% lower } \\
\text { limit }\end{array}$ & $\begin{array}{l}\text { IC 95\% } \\
\text { upper limit }\end{array}$ & $\mathbf{P}$ \\
\hline TAC (moles/L) & -0.00053 & -0.0007 I 78 & -0.000352 & $<0.000$ \\
$\mathrm{Sat}_{2}$ & $-0.0034 \mathrm{I}$ & $-0.0068 \mathrm{II}$ & $-3.34 \mathrm{e}-06$ & 0.05 \\
\hline
\end{tabular}

\section{Discussion}

One of the important findings in our work is based on the fact that serum levels of $\mathrm{S} 100 \beta$ protein previous to cardiac surgery are significatively and consistently (statistically significant derived from our previous study ${ }^{17}$ higher in the group with congenital heart disease with neurological perinatal antecedents than with the group that has not these perinatal antecedents. This suggests that the pre-surgical pathological conditions of the patients in relation to brain damage might very well be conditioned by the biological status arrival to the surgical act itself.

The mechanisms that contribute to the brain damage in pediatric patients with congenital heart disease are complex, multifactorial and not by far well known and the vast literature for decades is a testimony of this. This mechanisms are present since the prenatal period (product of structural cerebral malformations, coincident or because of hemodynamic alterations and metabolically issues during fetal life), or post-natal, because of chronic hypoxia, alterations of cerebrovascular regulation, hypoxic-ischemic events secondary to hemodynamic instability or embolic phenomena. All these possible events and insults contribute to elevate $\mathrm{S} 100 \beta$ in our series. Even though in this specific study we did not measure the protein during intra cardiac surgery and post-operatively, we know through our previous pilot study ${ }^{17}$ that there are events that raise the levels further, like PBP timing, hypothermia, hemodilution, or in the post-operatory (low volumes, convulsive crisis, sepsis and others), but of course there are lots of noise added because of anesthetic procedures, catastrophic hypoxic events, medication, transfusions, etc. that raise the levels and it is hard to say which did elevate the levels for sure. ${ }^{18}$

There is knowledge that children with congenital heart disease, might have an abnormal cerebral development or at least retarded considering time.${ }^{19}$ Because of this it is important to have not the best of biomarkers, but a biomarker with high sensibility and specificity to determine the neurological outcome even before, not to say after cardiac corrective or palliative procedures.

The literature has mentioned protein $\mathrm{S} 100 \beta$ as a possible biomarker, it was discovered by Moore in 1965 when he isolated a subcelular fraction of Bovine brain. ${ }^{20}$ This fraction was called S100 because it's constituents are soluble in ammonium sulfate $100 \%$ saturated at neutral $\mathrm{pH}$. This protein forms part of a family of about 25 members (E-F Hand proteins Calcium binding) with various configurations: Units alpha or beta. The subunit $\beta-\beta$ (S100 $\beta$ is highly specific in the brain, glial cells and Schwann cells; $\alpha-\beta$ is in the glial system, and alpha-alpha we can find in striate muscle, heart and kidney. ${ }^{21-24}$

The synthesis of $\mathrm{S} 100$ is regulated by glial cells mainly astrocytes and has the capacity to regulate synaptic plasticity, ${ }^{25,26}$ most of the protein acts intracytoplasmatic, regulating $\mathrm{Ca}^{++}$, and transcription, axonal growth; when in the extracellular space it participates interacting with R:A:G:E receptors, elevates IL6 and 8,Glutamate; it has the characteristics of a growth factor. ${ }^{6,25,26}$

In our study the elevated serum levels are considered to be altered metabolism of astrocytes, acute events are most definitely associated to BBB disruption associated to acute insults being associated ${ }^{17,22,27-34}$ in which even migration from subependimarian areas is stopped as found in autopsies in our department by the author. Further imagenological studies and correlations are needed.

This protein has been considered a biomarker in various scenarios, Cerebral vascular event, Alzheimer, head trauma, damage to BBB, PBP. ${ }^{6,35-42}$

On the other hand it is known that oxidative stress occurs at neurological level when generation of free radicals exceeds the defense antioxidant mechanisms.

The serum concentrations of different oxidants (MDA, NO, $\mathrm{NO}_{2}$, and $\mathrm{NO}_{3}$ ) can be and were measured aside, but TAC may resume it all, evidencing the antioxidative status of plasma. ${ }^{43-45}$

In our study there was an inverse proportional relation between pre-operative TAC and levels of S100 $\beta$. Besides, the group with neurological perinatal antecedents had a major significative presence in the cyanotic cardiopathies, patients with brain damage probability, chronic hypoxia and cardiac arrest, compared to the group without perinatal antecedents. The inverse relation between TAC and S100 $\beta$ levels can be explained by the tolerance developed by chronic hypoxic patients (cyanotic) through preaconditioning in which sublethal hypoxic insults, over express transcription protecting hypoxia factors observed in various tissues, renal, cardiac, cerebral, hepatic. ${ }^{46}$ This mechanisms involve TIF1 Alpha and HIF (transcription inductible and Hypoxia inductible factors) that regulate genes in response to cellular hypoxia and make them more resistant to it (Chronic) by means of anaerobic glycolisis and preserving mitochondrial function. ${ }^{17,47}$ With low saturations observed in this study it is clear that this mechanisms are called for as well as the explanation of S100 $\beta$ high levels in the preoperative stage. Further specific correlations are needed.

We believe that $S 100 \beta$ is a biomarker if we fill the metabolic gaps and basic and clinical gaps surrounding it's anatomical and clinical interpretation and correlations surrounding hypoxic phenomena both chronic and acute and it's understanding might be twice important as to develop further research to blockade its effect on R.A.G.E. 
receptors through its TRKT12 link for a true brain protection during congenital heart disease surgery specially in non cyanotic congenital heart disease that do not seem to have this protective adaptative mechanisms of the cyanotic which is our current investigation.

\section{Acknowledgements}

None.

\section{Conflict of interest}

The author declares no conflict of interest.

\section{References}

1. Calderón Colmenero J. Introducción. In: Attie Calderón, Zabal Buendía, editors. Cardiología Pediátrica. México: Editorial Medicina Panamericana; 2013:3-17.

2. Abdul Khaliq H, Blasig IE, Baur MO, et al. Release of the cerebral protein S-100 into blood after reperfusion during cardiac operations in infants: is there a relation to oxygen radical-induced lipid peroxidation. $J$ Thorac Cardiovasc Surg. 1999;117(5):1027-1028.

3. Markowitz SD, Ichord RN, Wernovsky G, et al. Surrogate markers for neurological outcome in children after deep hypotermic circulatory arrest. Semin Cardiothorac Vasc Anesth. 2007;11(1):59-65.

4. Miller SF, Mc Quillen PS, Hamrick S, et al. Abnormal brain development in newborns with congenital heart disease. $N$ Engl J Med. 2007;357(19):1928-1938.

5. Ali MS, Harmer M, Vaughan R. Serum S100 protein as a marker of cerebral damage during cardiac surgery. Br J Anesth. 2000; 85(2):287298.

6. Aloe L. Rita Levi-Montalcini: The discovery of nerve growth factor and modern neurobiology. Trends Cell Biol. 2004;14(7):395-399.

7. Calderón Colmenero J, Cervantes Salazar JL, Curi Curi PJ, et al. Problemática de las cardiopatías congénitas en México. Propuesta de regionalización. Arch Cardiol Mex. 2010;80(2):133-140.

8. Carrillo González NJ, Ortuño Sahagún D, Gudiño Cabrera C. Identificación de isoformas del mRNA del GFAP (Proteína Fibrilar Glial Acídica) en distintas regiones del sistema nervioso de la rata adulta. In: Avances en la investigación Cientifica en el CUCBA. Guadalajara, México: U. de G; 2005:240-245.

9. Charpentier TH, Thompson LE, Liriano MA, et al. The effects of Cap $\mathrm{Z}$ peptide (TRTK-12) binding to $\mathrm{S} 100 \mathrm{~B}-\mathrm{Ca}^{2+}$ as examined by NMR and X-ray crystallography. J Mol Biol. 2010;396(5):1227-1243.

10. Claus W, Heizmann, Beat W. The family of S100 cell signaling proteins In: Ralph A, Bradshaw, editors. Handbook of Cell Signaling. UK, Oxford: Academic Press; 2009:983-994.

11. Curi Curi PJ, Cervantes Salazar J, Calderón Colmenero J, et al. Resultados inmediatos en cirugía cardiovascular neonatal. Rev Invest Clin. 2012;64(2):199-206.

12. Blomquist S, Johnsson P, Lührs C, et al. The appearance of S-100 protein in serum during and immediately after cardiopulmonary bypass surgery: a possible marker for cerebral injury. J Cardiothorac Vasc Anesth. 1997;11(6):699-703.

13. Breuer AC, Franco I, Marzewski D. Left ventricular thrombi seen by ventriculography are a significant risk factor for stroke in open-heart surgery. Ann Neurol. 1981;10:103-104.
14. Donato R. Functional roles of $\mathrm{S} 100$ proteins, calcium-binding proteins of the EF-hand type. Biochim Biophys Acta. 1999;1450(3):191-231.

15. Drohat AC, Nenortas E, Beckett D, et al. Oligomerization state of S100B at nanomolar concentration determined by large-zone analytical gel filtration chromatography. Protein Sci. 1997;6(7):1577-1582.

16. Apak R, Güçlü K, Ozyürek M, et al. Cupric ion reducing antioxidant capacity assay for antioxidants in human serum and for hydroxyl radical scavengers. Methods Mol Biol. 2010; 594:215-239.

17. Pando Orellana LA, Springall R, Bojalil R, et al. Proteína S100B como marcador sérico predictivo del estado neurológico y del resultado postoperatorio en los pacientes pediátricos con cardiopatía congénita: un estudio piloto. In: III Congreso Nacional AMECC 2012. Querétaro, México; 2012.

18. Licht DJ, Shera DM, Clancy RR, et al. Brain maturation is delayed in infants with complex congenital heart disease. J Thorac Cardiovasc Surg. 2009;137(3):529-537.

19. Volpe JJ. Neurobiology of periventricular leukomalacia in the premature infant. Pediatr Res. 2001;50(5):553-562.

20. Moore BW. A soluble protein characteristic of the nervous system. Biochem Biophys Res Commun. 1965;19(6):739-744.

21. Aurell A, Rosengren LE, Karlsson B, et al. Determination of S-100 and glial fibrillary acidic protein concentrations in cerebrospinal fluid after brain infarction. Stroke. 1991;22(10):1254-1258.

22. Donato R. S100: a multigenic family of calcium-modulated proteins of the EF-Hand type with intracellular and extracellular roles. Int J Biochem Cell Biol. 2001;33(7):637-668.

23. Marshak DR, Pesce SA, Stanley LC, et al. Increased S100 beta neurotrophic activity in Alzheimer's disease temporal lobe. Neurobiol Aging. 1992;13(1):1-7.

24. Usui A, Kato K, Abe T, et al. S-100ao protein in blood and urine during open-heart surgery. Clin Chem. 1989;35(9):1942-1944.

25. Vaage J. Anderson R. Biochemical markers of neurologic injury in cardiac surgery: the rise and fall of S100beta. J Thorac Cardiovasc Surg. 2001;122:853-855.

26. Zimmer DB, Cornwall EH, Landar A, et al. The S100 protein family: history, function, and expression. Brain Res Bull. 1995;37(4):417-429.

27. Selinfruend R, Barger SW, Pledger WJ, et al. Neurotrophic protein S100B stimulates glial cell proliferation. Proc Natl Acad Sci USA. 1991;88(9):3554-3558.

28. Fanó G, Mariggió MA, Angelella P, et al. The S-100 protein causes an increase of intracellular calcium and death of PC12 cells. Neuroscience. 1993;53(4):919-925.

29. Haglid KG, Yang Q, Hamberger A, et al. S-100beta stimulates neurite outgrowth in the rat sciatic nerve grafted with acellular muscle transplants. Brain Res. 1997;753(2):196-201.

30. Merkle FT, Tramontin AD, Garcia Verdugo JM, et al. Radial glia rise to adult neural stem cells in the subventricular zone. Proc Natl Acad Sci USA. 2004;101(50):17528-17532.

31. Fujita Y, Kuchimaru T, Kadonosono T, et al. In vivo imaging of brain ischemia using an oxygen-dependent degradative fusion protein probe. PLoS One. 2012;7(10):1-7.

32. Rosén H, Rosengren L, Herlitz J, et al. Increased serum levels of the S-100 protein are associated with hypoxic brain damage after cardiac arrest. Stroke. 1998;29(2):473-477. 
33. Routsi C, Stamataki E, Nanas S, et al. Increased levels of serum S100B protein in critically ill patients without brain injury. Shock. 2006;26(1):20 24.

34. Gazzolo D, Vinesi P, Geloso MC, et al. S100 blood concentrations in children subjected to cardiopulmonary by-pass. Clin Chem. 1988;44(5):1058-1060

35. Sanchez Peña P, Pereira AR, Souror NA, et al. S100B as an additional prognostic marker in subarachnoid aneurysmal hemorrhage. Crit Care Med. 2008;36(8):2267-2273.

36. Fillipidis AS, Papadopoulos DC, Kapsalaki EZ, et al. Role of the S100B serum biomarker in the treatment of children suffering from mild traumatic brain injury. Neurosurg Focus. 2010;29(5):E2.

37. Ingebrigtsen $\mathrm{T}$, Rommer $\mathrm{B}$, Kongstad $\mathrm{P}$, et al. Increased serum concentrations of protein S-100 after minor head injury: a biochemical serum marker with prognostic value. J Neurol Neurosurg Psychiatry. 1995;59(1):103-104.

38. Kilminster S, Treasure T, McMillan T, et al. Neuropsychological change and S-100 protein release in 130 unselected patients undergoing cardiac surgery. Stroke. 1999;30(9):1869-1874.

39. Marenholz I, Heizmann CW, Fritz. G. S100 proteins in mouse and man: from evolution to function and pathology (including an update of the nomenclature). Biochem Biophys Res Commun. 2004;322(4):1111-1122.
40. Multicenter trial of hemodilution in ischemic stroke: background and study protocol. Scandinavian Stroke Group. Stroke. 1985;16(5):885-890.

41. Waterloo K, Ingebrigtsen T, Rommer B. Neuropsychological function in patients with increased serum levels of protein S-100 after minor head injury. Acta Neurochir. 1997;139(1):26-32.

42. Mori T, Asano T, Town T. Targeting S100B in Cerebral ischemia and in Alzheimer's disease. Cardiovasc Psychiatry Neurol. 2010;2010:1-14.

43. Gazzolo D, Vinesi P, Geloso MC, et al. S100 blood concentrations in children subjected to cardiopulmonary by-pass. Clin Chem. 1988;44(5):1058-1060

44. Pyles LA, Fortney JE, Kudlak JJ, et al. Plasma antioxidant depletion after cardiopulmonary bypass in operations for congenital heart disease. $J$ Thorac Cardiovasc Surg. 1995;110(1):165-171

45. Erel O. A novel automated method to measure total antioxidant response against potent free radical reactions. Clin Biochem. 2004;37(2):112-119.

46. Gidday JM. Cerebral preconditioning and ischaemic tolerance. Nat Rev Neurosci. 2006;7(6):437-488.

47. Isobe $\mathrm{T}$, Takahashi $\mathrm{K}$, Okuyama T. S100a0 (alpha alpha) protein is presen in neurons of the central and peripheral nervous system. J Neurochem. 1984;43(5):1494-1496. 